IZA DP No. 1140

The Distribution of Wages in Belarus

Francesco Pastore

Alina Verashchagina

May 2004 


\title{
The Distribution of Wages in Belarus
}

\author{
Francesco Pastore \\ Seconda Università di Napoli \\ and IZA Bonn
}

Alina Verashchagina

Belarusian National Technical University

Discussion Paper No. 1140

May 2004

IZA

P.O. Box 7240

53072 Bonn

Germany

Phone: +49-228-3894-0

Fax: +49-228-3894-180

Email: iza@iza.org

\begin{abstract}
Any opinions expressed here are those of the author(s) and not those of the institute. Research disseminated by IZA may include views on policy, but the institute itself takes no institutional policy positions.

The Institute for the Study of Labor (IZA) in Bonn is a local and virtual international research center and a place of communication between science, politics and business. IZA is an independent nonprofit company supported by Deutsche Post World Net. The center is associated with the University of Bonn and offers a stimulating research environment through its research networks, research support, and visitors and doctoral programs. IZA engages in (i) original and internationally competitive research in all fields of labor economics, (ii) development of policy concepts, and (iii) dissemination of research
\end{abstract} results and concepts to the interested public.

IZA Discussion Papers often represent preliminary work and are circulated to encourage discussion. Citation of such a paper should account for its provisional character. A revised version may be available on the IZA website (www.iza.org) or directly from the author. 


\section{ABSTRACT}

\section{The Distribution of Wages in Belarus*}

This paper uncovers evidence on the distribution of wages in Belarus in the second half of the 1990s. The returns to education and work experience are high and stable, which is atypical for a transition country. This might be due to the pervasive role of the state in fixing wages in the dominant budget sector, rather than to market forces coming into play. Women experience contained, though largely unexplained discrimination coupled with higher than average returns to education. A wage curve effect is found, which is similar in size to that of other transition countries, but much higher than in market economies.

JEL Classification: D31, J31, P2

Keywords: wage distribution, returns to education, gender wage gap, wage curve, Belarus

Corresponding author:

Francesco Pastore

Seconda Università di Napoli

Via Mazzocchi 5

81056 Santa Maria Capua Vetere (CE)

Italy

Tel./Fax: +39815 495276

Email: fpastore@unina.it

\footnotetext{
* An earlier version of this paper was selected as finalist for a research medal at the IV GDN Conference, held in Cairo, and presented at the XVII AIEL Conference. We thank Byung-Yeong Kim, Andrew Newell, Niall O'Higgins and Barry Reilly for useful comments. Verashchagina gratefully acknowledges the CNR-NATO Outreach Fellowships programme, which allowed her to carry out this research at the Department of Theoretical and Applied Economics, University of Naples "Federico II". She thanks the Department for the kind hospitality. However, all this considered, the usual disclaimer applies.
} 


\section{Introduction}

This paper uncovers empirical evidence on the distribution of wages in Belarus. Despite the negligence of the international literature (see the comprehensive studies contained in Brainerd, 1997; Newell and Reilly, 1999; Svejnar, 1999; and, for an explanation of such negligence, Havrylyshyn, 2001), the case under scrutiny is very interesting, since, contrary to the expectations, the extremely gradualist approach to economic reforms brought about together with persistent abnormal financial instability, also fast output recovery, compared to that in the neighbouring countries. Section one shortly describes the country's reform path and the so-called tariff system, a centrally determined wage grid, inherited from the pre-transition period. It also gives on overview of the debate on the distribution of wages in transition countries.

The remaining of the paper deals with three main issues, starting from the analysis of returns to education based on the 1996 and 2001 waves of the Belarusian Household Survey on Incomes and Expenditures (section two). Note that Belarus has always scored one of the highest ranks of the Human Development Index (HDI, UNDP, 2001) in the Commonwealth of Independent States (CIS), essentially for the high level of human capital accumulation. Then, the question arises of how the on-going economic transformations affected its returns. In particular, how big is the premium for University graduates? How does it compare with that in other transition countries? We find that the annual rate of return to one year of education is quite high, higher than in other transition countries and argue that this is not only because of the fearful attempts to introduce market mechanisms, but, more likely, because of the pervasive role of the state in fixing wages directly in the budget sector and indirectly in the small and dependent private sector. In fact, the tariff system has a remarkable regressive nature, as documented in Vaneev et al. (2001) and also argued in Katz (1999).

Two other aspects of the wage distribution have been given particular attention, namely the gender wage gap (section three) and the regional distribution of wages (section four). They 
are taken as tests of the expectations about how reforms affected the key mechanisms of labour market regulation. The estimates provide evidence of contained, though largely unexplained gender discrimination and large regional differentials.

Decomposition analysis of the gender wage gap is based on the method prompted in Oaxaca and Ransom (1994). Pooled Mincerian estimates provide the non-discriminatory set of coefficients used as weights of differences in characteristics by gender to measure their impact on the gender wage gap. A dummy for women is used to measure the ceteris paribus gender wage gap. The analysis shows that the unconditional is smaller (about $11 \%$ in both the considered years) than the conditional (19\%) gender wage gap. This suggests that despite women tending to have higher educational levels than men, they have lower wages, which points to a large size of the unexplained component of the gap.

Finally, this paper provides prima facie evidence of the existence of a wage curve effect in Belarus. The coefficients for the local unemployment rate used as a regressor in a Mincerian setting equal -0.23 in 1996 and -0.36 in 2001 . They are remarkably higher than that of -0.1 found in Blanchflower and Oswald (1994) for market economies and compare well to those given in Blanchflower (2001) for several transition economies. They imply that doubling the local unemployment rate correlates with a wage reduction of 23 percent in 1996 and 36 percent in 2001. This is circumstantial evidence of some degree of wage flexibility to unemployment differentials.

\section{The Belarusian Economy}

\subsection{The path of economic transition}

Economic transition in Belarus has been following quite an atypical path, also compared to other CIS republics (Havrylyshin, 2001, p. 57) ${ }^{1}$. More than by a comprehensive reform

1 In his survey of the literature on economic growth in transition countries, Havrylyshyn (2001, p. 57) claims that "Belarus and Uzbekistan may have been special cases of delayed reforms delaying the post-Soviet decline-at the very least, 
programme or a drastic privatisation plan, the transformation was driven by the disintegration of the former Soviet Union (FSU) planning system. To gauge the impact of this dramatic event on the Belarusian economy, consider that Belarus was the FSU country most dependent on interregional trade, apart from Latvia. Before transition, Belarusian exports to and imports from the FSU countries accounted for over 90 and $75 \%$ of total trade, respectively. Over $50 \%$ of the input (output) used (produced) by Belarusian firms was coming (going) from (to) other FSU republics. Moreover, manufacturing was the most important exporting sector, representing over $90 \%$ of foreign trade. The disruption of existing trade links explains large part of the country's economic downturn, which was in fact led by the fall in industrial output, by about $39 \%$. In the following years, it was the slow, but steady revival of the manufacturing sector itself to lead the recovery in output (Bakanova et al., 2001) ${ }^{2}$.

Privatisation was implemented at a quite slow pace, also compared to the other slow CIS countries. The production of private firms accounted only for $20 \%$ of GDP in 2001, the lowest share within the CIS. According to the World Bank (2002, p. 8), the share of private did not account for more than 11 percent of total employment in 1999.

they provide fodder for debate". "Belarus remains an understudied case, but three points suggest the numbers overstate performance or its sustainability. Much of its growth was based on export to Russia bartered for energy and other products; its largely unreformed system meant a high degree of directed credits to the economy and a much higher inflation than its neighbours; and after the Russian crisis its exports and growth fell sharply" (p. 69). Moreover, "A continuing puzzle remains on the low decline and high growth of Belarus and Uzbekistan. Certainly, the authorities of these countries and many critics of the standard reform school continue to point to these cases as successful gradual reforms. But even official figures show that growth there has slowed a lot, while the rest of the CIS show an accelerating trend" (p. 82). The emphasis is added to the text.

2 Blanchard and Kremer (1997) provide a formal explanation of the process that led the former Soviet Union republics to experience such a dramatic output fall, even in the absence of radical reforms. The Authors hypothesise that the disruption of the previous trade links due to the interruption of the planning system of resources' allocation in the absence of private firms led to disorganisation, i.e. mistrust among economic agents, making it convenient not to produce. 
A slow process of privatisation and trade liberalisation was coupled with almost complete price (but not wage) liberalisation ${ }^{3}$. As a result, the market essentially drove the process of reallocation of resources' via price adjustment. All over the 1990s, the annual price growth was always at two, three or even four digits, peaking at 2,221\% in 1994 . Since then, inflation has been fluctuating, with a negative trend, reaching $60 \%$ in 2001 , essentially thanks to tightening monetary policy. However, the Belarusian inflation rate remains the highest in the area (UNICEF, 2000, Tab. 9.4).

The explosion of prices in 1994 could not be absorbed by an equal increase in nominal wages, bringing about a dramatic reduction in their purchasing power from $84.9 \%$ to $68.7 \%$ of the 1990 level, a record for a one-year change. Since 1996 real wages have increased dramatically after GDP, reaching, in $2000,90 \%$ of the 1990 level $^{4}$.

Over the first half of the 1990s, employment shrank by more than 2 times less $(-14.4 \%)$ than GDP (-35.4\%) (Vaneev et al., 2001). The slow increase in unemployment was mainly the consequence of the government's attitude towards preventing mass open unemployment, even at the cost of efficiency. Wages were kept at the minimum possible level, using various means, including in-kind payments and wage arrears. Thanks to this policy, the official unemployment rate remained always below $4 \%$ all over the $1990 \mathrm{~s}^{5}$.

Looking at the structure of unemployment in the country based on official statistics (Ministry of Statistics, 2001), one learns that the most vulnerable category of population includes young women with low education and little work experience. Among young

3 This type of economic system could be called market socialism or, more accurately, state capitalism, since firms are state, rather than labour managed.

${ }^{4}$ During the second half of the 1990s, despite the slow and incomplete reform process, Belarus experienced a dramatic increase in GDP. By the end of 2001, Belarus and Uzbekistan were the only CIS countries where GDP overcame the $90 \%$ threshold of the pre-transition level.

\footnotetext{
${ }^{5}$ Though unions claim that the actual rate of unemployment would be around 8-10\% (Vaneev et al., 2001)
} 
unemployed, about 20 percent has attained general secondary education, a two-year programme which is considered preliminary to access the University.

\subsection{Wage regulation in Belarus}

More than ten years after the collapse of the Soviet Union, the Belarusian labour market is still far from liberalised. Important elements of the central-planning system are still in place. In principle, the decision to determine wages is left to firms, but the Government can affect the structure of wages through the so-called tariff system, a type of centrally determined wage grid. The tariff system is binding in the budget sector, including enterprises and organisations mainly financed and subsidised within the state and/or the local budgets. The private (so-called self-financing sector) sector, representing, as already noted, only a small share of employment, has little autonomy ${ }^{6}$.

Tariff wages in the budget sector are determined on the basis of a tariffs scale, a tariff rate of the first grade, a tariff qualification guide. The tariffs scale is a system of coefficients measuring the ratio of the wage of each class to the lowest one (so-called first grade). The tariff qualification guide contains detailed characteristics and rank order of professions and types of labour. There is also an over-tariff part of wages. It implies premiums and additional payments, which depend on productivity, budget allowances and so on ${ }^{7}$. The tariff scale worked already under the Soviet Union and since 1992 it was continuously revised, mainly to take into account the effects of hyperinflation ${ }^{8}$.

The current tariff scale includes 28 classes. This itself implies wide earnings dispersion. The ratio between the highest and the lowest ranks equals 8.39. However, the lowest 9 classes

\footnotetext{
${ }^{6}$ In principle, the system is only recommended to private firms. As a matter of fact, from 1992 to 1997 , all private enterprises were using the first wage class fixed by the government for the budget sector.

${ }^{7}$ Premiums can be up to $30 \%$ of the basic pay for the years of tenure; and up to $50 \%$ for other reasons.

${ }^{8}$ Each new version is approved by a corresponding government act, decided on the basis of a tripartite bargaining process with unions and entrepreneurial organisations.
} 
are given additional subsidies from the state. Taking them into account the ratio between the highest and the lowest class becomes 5.03. The growth rate of the coefficients from the $1^{\text {st }}$ to the $4^{\text {th }}$ class equals 1.16 . For the $5^{\text {th }}$ and the $6^{\text {th }}$ class it becomes 1.10 . From the $7^{\text {th }}$ to the $28^{\text {th }}$ it is 1.07 . Therefore, although adjusted by a pervasive system of subsidies in favour of workers in the lowest ranks, the wage grid has a regressive nature. This is an important point to bear in mind, as it could partly explain the high degree of wage inequality typical of FSU countries, noted in the literature (Atkinson and Micklewright, 1992; Newell and Reilly, 1999; Katz, 1999). It could also partly explain the high returns to educational qualifications found in the estimates of earnings equations relative to Belarus. Overall, in fact, the ranks mainly depend on the level of educational attainment and years of work experience ${ }^{9}$.

A particular problem regards the lowest wage classes, the most hit by inflation. The tariff of the first grade should be equal to (or higher than) the minimum wage fixed by the government. However, during the years 1992-'96 the tariff of the first grade was only from 5 to 18\% higher than the minimum wage. In 1998 the first grade was fixed at 2 times the minimum wage.

\subsection{Inequality and earnings in transition countries}

The figures in Table 1 on the Gini coefficient in various transition countries suggest that wage inequality dramatically increased when transition started. The CIS countries had a higher degree of wage inequality than the countries in Central and Eastern Europe already at the outset of transition, but experienced also the largest increase in inequality. However, Belarus has one of the lowest and most stable levels of Gini inequality.

[Table 1 about here]

A puzzle of the economic transition literature is the contrast between the high and increasing degree of inequality and the remarkably low returns to human capital. Large

\footnotetext{
${ }^{9}$ In special cases improvements in rank can be obtained also as a premium.
} 
evidence relative to several Central and Eastern European Countries (CEECs) as well as countries in the CIS both in the pre- and post-transition era suggests that the increase in the return to education was slower than expected. Moreover, generic and, even more so, jobspecific work experience exhibit a lower return than in Western countries, also when combined with high education attainment. The returns to work experience appear in some CIS republics dramatically decreasing over time. The low returns to human capital is often interpreted as one of the heritages of the socialist system or, in the case of work experience, as the consequence of the weakening of seniority rules (see, among others, Atkinson and Mickelwright, 1992; Orazem and Vodopivec, 1997; Newell and Reilly, 1999; Svejnar, 1999).

Newell (2001) suggests that the increased wage inequality might be explained by sectoral shifts in employment and increasing inter-industry wage differentials, rather than by changes in hourly wage inequality. In the case of Poland, rising inequality appears to be entirely accounted for by an increased incidence of workless households, due, in turn, to rising participation in post-compulsory education and earlier retirement.

What are the main causes of sectoral shifts over transition? And why the returns to education were so low and stable? On the demand side, a skill biased technical change, adopted also defensively to deal with international competition, together with some specific features of economic transition, such as the shift towards the production of consumer goods, should tend the returns to education to increase. On the supply side, the remarkable increase observed in the last two decades in the share of workers with high levels of human capital could have reduced the skill premium. Though, as noted in Acemoglu (2002), within the context of models with endogenous technical change, a sufficiently sizeable and continuous increase in the supply of human capital could accelerate the move towards skill-intensive productions, causing a further increase in the skill premium. The overall effect would depend on the relative increase in the demand for and supply of human capital. 
Are there transition specific factors at work? Orazem and Vodopivec (1997), Aghion and Commander (1999) and Sabirianova (2003) point out three main specific forces. Firstly, the removal of the government's power to set wages, which supposedly prevented the emergence of high returns to education under central planning. Secondly, dramatic shifts in the composition of final demand for goods from low skill intensive heavy manufacturing and agriculture to light manufacturing and service industry. This implies a positive shift in favour of high skill labour and of women, since many industries specialised in consumption goods are generally female-dominated. Thirdly, putting an end to the planned economy implies a shortterm increase in the level of uncertainty of any economic activity, increasing the need for high skilled workers able to bear and control for risk.

In the case of Belarus, a relatively low and stable Gini coefficient mirrors the substantial stability of the production system, depending, in turn, also on the slowness of the reform programme. In the following section, the issue is dealt with considering, first, the slow evolution of the economic structure and the overall distribution of earnings by education.

\section{Returns to education}

The estimates are based on the Belarusian Household Survey on Incomes and Expenditures, started in 1995. With about 5,000 households interviewed every year, it represents the most comprehensive source of micro-data in the country. This study is based on the 1996 and 2001 waves. As already noted, the year 1996 can be considered a turning point in the history of the country's transition, when the first signs of GDP recovery appeared after a sharp decline.

\subsection{The Mincerian framework}

The generic augmented version of the Mincerian specification of the earnings equation is as follows: 


$$
\ln w_{i}=\mathbf{X}_{\mathbf{i}} \boldsymbol{\beta}+r s_{i}+\delta x_{i}+\gamma x_{i}^{2}+u_{i}
$$

where $w_{i}$ represents earnings for an individual $i, s_{i}$ represents a measure of his schooling, $x_{i}$ is an experience measure, $\mathbf{X}_{\mathbf{i}}$ is a set of other variables assumed to affect earnings, and $u_{i}$ is a disturbance term representing other forces which may not be explicitly measured, assumed independent of $\mathbf{X i}$ and si. Note that experience is included as a quadratic term to capture the concavity of the earnings profile. $r$ can be considered the private financial return to schooling as well as being the proportionate effect on wages of an increment to $s$. The above earnings function is in fact a log-linear transformation of an exponential function and can be estimated by OLS.

In the estimates presented here, the dependent variable is the natural logarithm of the average net monthly wage from the main job (Wage 1$)^{10}$. The total net monthly labour income (Wage2), including also subsidies and in-kind payments from the main job, incomes from secondary jobs, pensions, unemployment benefits and so on, is also used as a dependent variable. This variable is expected to catch the role of State compensation mechanisms in mitigating the regressive nature of the tariff system. Table A.1 in the Appendix gives detailed definitions of these and other variables.

Minor changes to the questionnaire have been imposed over the years. The main difference between 1996 and 2001 refers to the educational variable. In 1996, respondents were asked to declare their years of school attendance up to general secondary school and their upper educational qualification, separately. In 2001, respondents provide information on levels of educational attainment in one single question. To make the estimates easier to compare, levels of educational attainment are used in the estimates.

Two other variables are worth mentioning. Belarus is on the Western border of the former Soviet Union and conspicuous resources were destined in the pre-transition era to the military

10 In the available release, there is no information on the working hours and on other variables, such as the ownership type, the industrial sector and so on. 
sector. Moreover, people serving in the army were given high and specialised education. In the early 2000s, a sizeable share of workers was still serving in the army. A dummy is used to test for the presence of a ceteris paribus payoff in favour of this group.

Moreover, Belarus was one of the countries most hit by the Chernobyl disaster, causing in many cases unusual malformation and cancers. All over the 1990s, the Government provided a special subsidy to those involved, though this subsidy was progressively reduced in the second half of the 1990s.

\subsection{The composition of employment and wages}

The analysis in section one provided a theoretical framework to look at the market for human capital over economic transition. In what respect does Belarus differ from other transition countries? It was noted that the Gini index of inequality was lower than in other CIS as well as in Central and Eastern European countries, though it was similar to the OECD average, and stable over time. How strong were demand and supply shifts in the labour market? How sizeable are the returns to education in Belarus? The first point to assess is the size and direction of shifts in the sectoral composition of employment and participation. Different from other transition countries, the shares of employment, unemployment and inactivity remained remarkably stable over the 1990s. Table 2 shows that also the employment composition by sector remained stable. Though, the share of employment in manufacturing and agriculture slightly decreased, in favour of that in the service sector. Note that the most important changes happened in the first half of the 1990s, a period that the BHSIE does not cover.

[Table 2 about here]

The distribution of occupations by educational attainment in 1996 and 2001 based on the BHSIE does not show any major surprise and is therefore omitted. As expected, workers holding a University degree tend to concentrate in white-collar jobs or are self-employed. 
Blue-collar workers, instead, to a large extent, have vocational or general secondary qualification, when not compulsory education. Over the period, the share of blue and whitecollar workers increased whereas that of farmers slightly decreased. The differences in the group of highly educated workers are negligible, except for a remarkable reduction in the number of self-employed and a smaller reduction among those serving in the army.

On the supply side, the number of people with high secondary or tertiary education increased dramatically especially over the period from 1985 to 1995 . The share of employed workers with at least tertiary education attainment reached about $18.8 \%$ in 2000 , which compares to an OECD average of $23 \%$. In the previous and following period, the number of workers with high educational attainment increased at a slower pace. Based on this evidence, ceteris paribus one would expect the returns to education to be stable over the second half of the 1990s.

Table 3 informs on the distribution of unconditional average net monthly wages by educational qualification for the entire sample. The table also provides the ratio of the wage of individuals with high education to the group with compulsory education or below $(I)$. The numbers between brackets measure the ratio of the overall labour income (Wage2) to the earnings from the main job (Wage1). The table shows that in both cases, wages are shaped according to the level of education achieved. Workers with a university degree obtain remarkably higher wages from their job, about two and a half times higher than the base category. This is quite a high skill payoff, which contrasts with the fact that the average income in Belarus is much lower than the OECD average as well as that of most neighbouring countries, including Russia.

\section{[Table 3 about here]}

As expected, the distribution of the overall labour earnings by education reported in the last column of table 3 is flatter. Except for the group with the highest educational level, the share of the overall labour income over the wage from the main job is higher for those with 
low educational levels, especially those with compulsory education or below. The reason could be the aforementioned more progressive nature of subsidies and in-kind payments from the main job. Pensions and other subsidies, also included in Wage2, are attributed according to the same logic.

\subsection{Augmented earnings equations}

Table 4 presents the results of augmented earnings equation, controlling also for gender, other available variables and location. The overall goodness of fit is satisfactory for this type of estimates. The annual rate of return to post-compulsory education equals 10.1 and 10.3 percent in the two years considered for those who reached university education, which requires seven additional years compared to compulsory education ${ }^{11}$. These returns are remarkably higher than in other transition countries. One additional year of post-compulsory education after completing technical (four additional years), vocational (three additional years) and general secondary (two additional years) school provided a return of 11.5, 6 and 10.5 percent in 1996 . The return to a university degree after obtaining a diploma of technical secondary school equals $8.3^{12}$.

The coefficient for the years of work experience is high and stable at about $5-6 \%$, confirming the importance of seniority rules also in contemporary Belarus. Moreover, despite being flat like in other countries, they show decreasing returns only to a minimum extent. This is a high premium to seniority also compared to other CEECs and is similar only to those of such CIS countries like Kyrgyzstan and Ukraine, where transition was very gradual. In fact, the

\footnotetext{
${ }^{11}$ This estimate is obtained dividing the coefficient for university education by the seven years that are necessary on
} average to obtain a university degree after finishing compulsory education: $r=\frac{\beta_{u}}{Y_{u}-Y_{c}}$. Multiplying this value for 100 gives the percentage change for every year of additional education.

$$
{ }^{12} \text { The formula becomes: } r=\frac{\beta_{u}-\beta_{s}}{Y_{u}-Y_{s}} \text {. }
$$


available literature on CIS countries provides a wide range of values for the annual return to work experience ${ }^{13}$. In augmented earnings functions it was, for instance, between 1.9 and 1.1 in Slovenia in 1987 and 1991 (Orazem and Vodopivec, 1997), between 3.1 and 2.1 in Poland from 1987 to 1993 (estimate based on household survey data, Rutkowski, 1996), slightly higher than 1 in Poland in 1996 (based on labour force survey data, Adamchik and Bedi, 2000). In some cases, such as Russia, they were very low all over the 1990s. In other CIS republics, they were high, but dramatically declined over the decade, as soon as market mechanism started to come into play and seniority rules to weaken. In Kyrgyzstan, for instance, they fell from 5.2 in 1993 to 1.3 in 1997 (Anderson and Pomfret, 2000).

The discrimination coefficient relative to disabled workers is sizeable and statistically significant, though decreasing over the period. The ceteris paribus wage from the main job of disabled people was about $63 \%$ lower than the median wage in 1996 . It became $34 \%$ lower in $2001^{14}$.

As already noted analysing unconditional wages, other sources of labour income introduce compensating mechanisms for low-wage workers. The returns to work experience shrink in both years when one considers the overall labour income (Wage2).

It is interesting to note that the returns to serving in the army, which was still very high in 1996 is dramatically shrinking recently. The wage premium of servicemen reduced from 86 to

\footnotetext{
${ }^{13}$ It should be noted that such comparisons should taken with caution, given that authors use different sets of regressors.

${ }^{14}$ In log-linear estimates the coefficients have a semi-elasticity interpretation. They measure the percentage change in the dependent variable for any unit change in the independent variable considered. When the regressor is a continuous variable, the elasticity at the mean of the covariates, namely the percentage change in the regressand for a percentage change in the regressor, can be computed multiplying the coefficient by the mean of the regressor: $\beta \bar{X}$. In the case of dummy variables, the semi-elasticity interpretation is flawed and, following Halvorsen and Palmquist (1980), it is computed as: $\left(e^{\beta}-1\right) * 100$. In this case, it measures the percentage change in the median wage, which is less affected by outliers. Nonetheless, many authors interpret the estimated coefficients of dummy variables directly as semi-elasticity. This is acceptable when the estimated coefficient is sufficiently close to zero.
} 
$35 \%$ of the median wage, mirroring the process of country's demilitarisation. This is the only case when additional sources of income increase the return to those who already have higher wages.

The Chernobyl wage gap, the loss of earnings potential experienced by workers involved in some way in the Chernobyl disaster, which was almost zero in 1996, amounts to about $18 \%$ of the median wage in 2001. The wage gap reduces when one considers all labour incomes, confirming that subsidies compensate the loss of earnings potential experienced by this group. Such compensations are much more sizeable in 2001, when the gap is higher in terms of incomes from the main job, but halved.

\section{[Table 4 about here]}

The analysis of augmented earnings equations suggests that Belarus is an exception compared to other transition countries, in as much as the Gini coefficient is lower, but the returns to human capital are higher than in CEE and in the CIS republics. Whether this is the consequence of market forces coming into play or of the pervasive role of the state in the process of wage determination is questionable. What can be excluded is the role of structural change, which was negligible in Belarus. The estimates presented here would tend to confirm the argument contained in Katz (1999), that returns to education and work experience were high, not low in the socialist system, though, as noted in Kornai (1992) this was some way to compensate high skill workers for the low average income.

\section{The gender wage gap}

The coefficient for the gender dummy in Table 4 is high at -0.20 , significant and stable over time, suggesting that ceteris paribus women' wages are lower than the median wage by slightly less than 20\%. Moreover, as other studies (Psacharopoulos, 1994) found, also in the case of transition countries (Orazem and Vodopivec, 1997), the returns to education are higher for women than for men. According to recent studies (see, among others, Dougherty, 2003), 
gender discrimination, taking the form of a gap in wage levels and employment opportunities, explains also the higher returns to education universally found for women. In fact, women tend to put greater effort than men in education, obtaining as a consequence, higher levels and quality of education. This is, in fact, perceived by the most skilled women as the best instrument to escape from discrimination.

To further investigate this issue, the gender wage gap is decomposed using the method prompted in Oaxaca and Ransom (1994). In short, pooled estimates provide the nondiscriminatory set of coefficients used as weights of differences in characteristics by gender to measure their impact on the gender wage gap. The general form of the applied mean wage decomposition is:

$$
\overline{\operatorname{Ln} W_{M}}-\overline{\operatorname{Ln} W_{W}}=\left(\bar{X}_{M}-\bar{X}_{W}\right) \hat{\beta}+\hat{\gamma} W
$$

where $\overline{\operatorname{Ln} W_{g}}$ and $\bar{X}_{g}$ represent the mean wage and control characteristics for all individuals in group $g$ (where $g=$ man or woman), $\hat{\beta}$ is the set of coefficients from the pooled regression, including men and women and $\hat{\gamma}$ is the estimated coefficient for the gender dummy. The first term in this decomposition represents the predicted gap between groups and the second term represents differences in gender-specific coefficients from the nondiscriminatory wage structure and is often interpreted as wage discrimination. However, it captures not only the discrimination effect, but also effects of unobserved group differences in productivity and tastes. Notice that the unexplained component of the gap is summarised by $\hat{\gamma}$, as suggested in Groshen (1991).

The Tables 6 and 7 presents the results of the decomposition analysis relative to both years and types of labour income considered. In each table, the columns (1) and (4) give a measure of the unconditional wage gap relative to 1996 and 2001, as obtained in a regression of wages on the gender dummy only. The columns (2) and (5) provide the coefficients of pooled regressions, where also regional dummies' coefficients are reported. The columns (3) and (6) 
give the differences in characteristics by gender. The last two columns measure in each year the absolute and relative contribution of each characteristics to the gender wage gap. The first cell of the columns (3) and (6) provide a measure of the log wage differential.

The analysis shows that the unconditional gender wage gap is smaller (about $11 \%$ in both years) than the conditional one (19\%). This apparently surprising result suggests that despite women tending to have higher educational levels than men, they have lower wages, which points to a large size of the unexplained component of the gap. In relative terms, the unexplained components of the gap amounts to 171 percent in 1996 and $181 \%$ in 2001 . The comparable figures for the total labour income based on Table 7 are 108 and 114.

The explained components of the gap are divided in four groups: education, work experience, location and other factors. Focusing on the wage from the main job (Table 6), it is noticeable that only the last one of these groups increases the gap (13\% in 1996 and only $9 \%$ in 2001). The most important factor, though with decreasing importance, is the higher share of men serving in the army, a high pay job in the country. The most important factors reducing the gap is education. Summing up the relative contribution of differences in productivity due to differences in educational qualifications amounts to an advantage for women of b50 and 40\% of the gap in 1996 and 2001, respectively. In 1996, there were about 3\% and $12.3 \%$ more women with university and technical school respectively than there were men. Men are more frequent among those with vocational and general secondary school. Women have less potential work experience than men, but considering the relative impact of the quadratic term the overall impact of this variable is negligible. Location reduces the gap by about $20 \%$ in both years.

\section{[Table 6 about here]}

The analysis of the overall labour incomes is slightly different. The gender wage gap is almost double that based on the earnings from the main job, which also implies a slightly lower unexplained component. The reduction in the unexplained component mainly depends on the 
fact that differences in educational levels become less important, when one considers this larger group of individuals, which lines towards the idea that the first form of discrimination for women is in terms of lower job opportunities. This finding confirms the hypothesis that subsidies and pensions are attributed based on redistributive criteria. Again there are little differences over the years.

\section{[Table 7 about here]}

For the large size of the unexplained component of the wage gap, the results relative to Belarus are close to those found in Katz (1997) for the Russian medium sized city of Taganrog in the early 1980s and early 1990s. Though, in Katz and other studies relative to Russia in the early 1990s (see, for a survey, Reilly, 2002), the female/male monthly pay ratio was much smaller than that relative to Belarus, suggesting a gender pay gap of over $30 \%$.

\section{The Belarusian wage curve}

One way to measure the degree of flexibility and efficient functioning of the Belarusian labour market is estimating the sensitivity of wages to local labour market conditions. The estimates in Table 7 suggest that conspicuous and significant regional wage differentials exist in Belarus. All other factors held constant, wages in Minsk are in some cases also twice bigger. Wages in large cities are generally higher than in small towns and rural areas, respectively. Though, taking into consideration other types of labour income, the geographical gap tends to reduce. This can be explained by the existence of larger opportunities in the small towns and rural areas in getting access to additional sources of income. Table 8 confirm the impression of large wages differentials across the six main Belarusian oblasts.

To test whether such wage differentials follow any unemployment pattern, in our estimates of table 5 we substitute regional unemployment rates (in natural logarithm) to regional dummies, in the way formalised in Blanchflower and Oswald (1994) to test for the existence of a wage curve. The main idea behind the wage curve is that wages should react to increased 
unemployment at a local level, after controlling for human capital levels and other determinants of individual earnings. There are various theories that could explain why this might be the case. The Authors assume that in non-competitive labour markets, an increase in the unemployment rate implies a reduction in the power of workers to make upward wage claims. A non-union interpretation of the wage curve would be given within the efficiency wage framework: with the local unemployment rate increasing, employers would be able to reduce the wage that insures the maximum productivity of workers. Considering that the Belarusian labour market is far from liberalised, perhaps the first interpretation is more convincing ${ }^{15}$. In any case, the greater is the sensitivity of wages to local labour market conditions, the faster is the adjustment process to adverse asymmetric shocks.

The results provide prima facie evidence of the existence of a wage curve in Belarus. The coefficient for the local unemployment rate variable is of -0.23 in 1996 and of -0.36 in 2001 . These coefficients are remarkably higher than that of -0.1 given in Blanchflower and Oswald (1994) for market economies and compare well to those given in Blanchflower (2001) for several transition economies ${ }^{16}$. They imply that doubling the local unemployment rate implies a wage reduction by 23 per cent in 1996 and by 36 per cent in 2001 .

No further attempt is carried out here to explain such large cross-regional differences. Nonetheless, it seems plausible to claim that this is evidence of a significant correlation between the level of unemployment and that of wages at a local level.

\footnotetext{
${ }^{15}$ In fact, in the case of Belarus, reducing wages when unemployment is high might be also a governmental policy to increase employment in backward areas. Alternatively, given the high degree of persistence of regional unemployment differentials and the tendency of unemployment to concentrate in small towns and rural areas, where the manufacturing sector is less sizeable, it might be that the power of unions is weaker in these areas.

${ }^{16}$ Svejnar (1999) reports that attempts to find evidence of a wage curve in transition countries based on the
} 


\section{Concluding remarks}

The extremely gradualist approach to economic transition in Belarus would contribute to form the expectation that the rate of return to education should be low and the profile of the return to work experience flat, like they supposedly were under central-planning. However, estimates of Mincerian earnings functions based on the 1996 and 2001 waves of the Belarusian Household Survey of Incomes and Expenditure (BHSIE) suggest that in fact the skill payoff is remarkably high, higher than in other transition countries in CEE and in the CIS. This holds true also for work experience, suggesting that seniority rules are important and that perhaps the high returns to education are partly the consequence of the inherited tariff system, rather than of market forces coming into play.

Other specific findings include the increasing degree of discrimination against disabled workers and individuals involved in the Chernobyl disaster. Moreover, some occupations, whose wage premium was traditionally and artificially high under socialism, experienced drastic earnings reductions. This is the case of workers serving in the army.

The paper provides also evidence of gender discrimination. Despite the higher returns to education of women, the gap amounts to about 10 percent of the log wage, a much lower figure than that found for Russia in previous studies. However, the Oaxaca and Ransom decomposition analysis suggests that similar to previous studies relative to FSU, the unexplained component of the gap is sizeable overweighing the negative impact of women's educational advantage.

Finally, the paper provides evidence of the existence of a sizeable wage curve effect in Belarus, suggesting that, similar to other transition countries, spatial wage differentials between low and high unemployment regions are important, also when compared to Western European countries. 


\section{References}

Acemoglu, D. 2002: Technical Change, Inequality and the Labour Market, Journal of Economic Literature, XL: 7-72.

Adamchik, V.A. and Bedi, A.S. 2000: Wage Differentials between the Public and the Private Sector: Evidence from an Economy in Transition, Labour Economics, 7(2): 203-224.

Aghion, P., and Commander, S. 1999: The Dynamics of Inequality in the Transition. Economics of Transition, special issue 7(2), pp. 275-298.

Anderson, K and Pomfret R. 2000: Gender Effects of Transition: The Case of the Kyrgyz Republic, Adelaide University, wp, n. 8.

Atkinson, AB and Micklewright, J. 1992: Economic Transformation in Eastern Europe and the Distribution of Income, Cambridge University Press, Cambridge.

Blanchard, OJ and Kremer, M. 1997: Disorganisation, Quarterly Journal of Economics, 112(4): 1091-1126.

Brainerd, E. 1997: Women in Transition: Change in Gender Wage Differentials in Eastern Europe and FSU, Williams College, Working Paper, n. 171.

Blanchflower, DG and Oswald, AJ. 1994: The wage curve, MIT Press, Cambridge, MA.

Blanchflower, D. 2001: Unemploymemt, Well-being and Wage curves in Eastern and Central Europe. Department of Economics Dartmouth College and NBER. NH 03755 , USA

Dougherty, C. 2003: Why is the Rate of Return to Schooling Higher for Women than for Men?, CEP Discussion Paper, August.

Groshen, EL. 1991: The structure of the female-male wage differential: Is it who you are, what you do, or where you work?", Journal of Human Resources, 26(3): 457-472.

Halvorsen, R and Palmquist, R. 1980: The Interpretation of Dummy Variables in Semilogarithimic Equations, American Economic Review, 70(3): 474-75.

Havrylyshyn, O. 2001: Recovery and Growth in Transition: A Decade of Evidence, IMF Staff Papers, 48, Special Issue: 53-87.

Katz, K. 1997: Gender, Wages and Discrimination: A Study of a Russian Industrial Town, Cambridge Journal of Economics, 21(4): 431-452.

Katz, K. 1999: Where there no Returns to Education in the USSR? Estimates from Soviet Household Data, Labour Economics, 6(3): 397-416.

Kornai, J. 1992: The Socialist System. The Political Economy of Communism. Oxford, Oxford University Press.

Ministry of Statistics. 2001: Trud i zanyatost v Respublike Belarus. Statisticheskiy sbornik, Belarus, Minsk.

Newell, A and Reilly, B. 1999: Rates of Return to Education in the Transitional Economies, Education Economics, 7(1): 67-84.

Newell, A. 2001: The Distribution of Wages in Transition Countries, IZA, Discussion Paper, n. 267, March.

Oaxaca, R and Ransom, M. 1994: On Discrimination and the Decomposition of Wage Differentials", Journal of econometrics, 61(1): 5-21.

Orazem, PF and Vodopivec, M. 1997: Value of Human Capital in Transition to Market: Evidence from Slovenia, European Economic Review, 41(3-5): 893-903.

Psacharopoulos, G. 1994: Returns to Investment in Education: a Global Update. World Development 22(9), $1325-1343$.

Reilly, B. 2002: The Gender Pay Gap in the Transitional Economies. A Survey of Existing Literature. University of Sussex, typescript.

Rutkowski, J. 1996: High skills pay-off: the changing wage structure during economic transition in Poland, Economics of Transition, 4(1): 89-111.

Sabirianova, K.P. 2003: Skill-Biased Transition: The Role of Market, Institutions, and Technical Change. IZA Discussion Paper, 893, October.

Svejnar, J. 1999: Labour Markets in the Transitional Central and East European Economies, in Ashenfelter, O. and D. Card (eds.), Handbook of Labour Economics, vol. 3b, Ch. 42: 2809-2857.

UNDP. 2001: Human Development Report, Washington.

UNICEF. 2000: Young People in Changing Societies, The MONEE Project CEE / CIS / Baltics, Regional Monitoring Report, n. 7.

Vaneev, DI, Gurskiy, IM, Kisel, EC.2001: Issledovanie rynka truda Belarusi, NII Truda, Minsk.

World Bank. 2002: Memorandum of the President of the International Bank for Reconstruction and Development and of the International Finance Corporation to the Executive Directors on a Country Assistance Strategy, February. 
Annex of tables

Table 1. Gini coefficient of income per capita, Various Years and countries

\begin{tabular}{lccc|lrrr}
\hline Countries & $1987-90$ & $1993-94$ & $1996-98$ & Countries & $1987-90$ & $1993-94$ & $1996-98$ \\
\hline Bulgaria & 0.23 & 0.38 & 0.41 & Armenia & 0.27 & 0.23 & 0.28 \\
Croatia & 0.36 & & 0.35 & Belarus & 0.26 \\
Czech Republic & 0.19 & 0.23 & 0.25 & Georgia & 0.29 & 0.30 & 0.33 \\
Hungary & 0.21 & 0.23 & 0.25 & Kazakhstan & 0.31 & 0.55 \\
Poland & 0.28 & 0.28 & 0.33 & Kyrgyz Republic & 0.27 & 0.26 \\
Romania & 0.23 & 0.29 & 0.30 & Moldova & 0.47 \\
Slovenia & 0.22 & 0.25 & 0.30 & Russia & 0.28 & 0.47 \\
Estonia & 0.24 & 0.35 & 0.37 & Tajikistan & 0.28 & 0.47 \\
Latvia & 0.24 & 0.31 & 0.32 & Turkmenistan & 0.36 \\
Lithuania & 0.23 & 0.37 & 0.34 & Ukraine & 0.45 \\
\hline
\end{tabular}

Source: World Bank (2002b). 
Table 2. Employment by sector (\%)

\begin{tabular}{lccc}
\hline & 1990 & 1996 & 2000 \\
\hline Industry & 30.9 & 27.5 & 27.6 \\
Agriculture & 19.1 & 17.4 & 14.1 \\
Construction & 11.1 & 7.2 & 7.0 \\
Transport & 6.0 & 5.8 & 5.8 \\
Trade and catering & 6.4 & 9.6 & 11.0 \\
Health and social services & 5.2 & 6.9 & 7.3 \\
Education & 8.4 & 9.9 & 10.4 \\
Other & 12.9 & 15.7 & 16.8 \\
\hline
\end{tabular}

Source: Ministry of statistics (2001). 
Table 3. Wages by educational levels, entire sample

\begin{tabular}{lcccc}
\hline Educational levels & Wagel & I & Wage2 & I \\
\hline $\mathbf{1 9 9 6}$ & & & & \\
\hline Doctorate & 1524.0 & 290 & $1908(125.2)$ & 331 \\
University degree & 1272.2 & 242 & $1309.9(103.0)$ & 227 \\
Technical secondary & 946.2 & 180 & $956.7(101.1)$ & 166 \\
Vocational secondary & 818.9 & 156 & $853.0(104.2)$ & 148 \\
General secondary & 768.0 & 146 & $808.9(105.3)$ & 140 \\
Compulsory education or below & 525.9 & 100 & $576.5(109.6)$ & 100 \\
\hline Number of observations & 6452 & & 9544 & \\
\hline 2001 & 156956.3 & 370 & $157293.8(100.2)$ & 298 \\
\hline Doctorate & 111374.4 & 262 & $114169.1(102.5)$ & 217 \\
University degree & 80728.6 & 190 & $82107.3(101.7)$ & 156 \\
Technical secondary & 77235.5 & 182 & $78950.4(102.2)$ & 150 \\
Vocational secondary & 67555.5 & 159 & $68883.6(102.0)$ & 131 \\
General secondary & 42441.7 & 100 & $52708.0(124.2)$ & 100 \\
Compulsory education or below & 6349 & & & \\
\hline Number of observations & & & & \\
\hline
\end{tabular}

Note: For the variables definition see the Table AI in the Appendix. "I" represents the index of wages of each educational group relative to that of workers with compulsory education or below $(=100)$. The figures between brackets measure the ratio of the overall labour income and the earnings from the main job (Wage2/Wage1).

Source: elaboration on the BHSIE. 
Table 4. Earnings equations for Belarus (1996, 2001)

\begin{tabular}{|c|c|c|c|c|c|c|c|c|c|c|c|c|}
\hline & \multicolumn{4}{|c|}{ All } & \multicolumn{4}{|c|}{ Men } & \multicolumn{4}{|c|}{ Women } \\
\hline & \multicolumn{2}{|c|}{1996} & \multicolumn{2}{|c|}{2001} & \multicolumn{2}{|c|}{1996} & \multicolumn{2}{|c|}{2001} & \multicolumn{2}{|c|}{1996} & \multicolumn{2}{|c|}{2001} \\
\hline & Wage1 & Wage 2 & Wage1 & Wage2 & Wage 1 & Wage2 & Wage1 & Wage2 & Wage 1 & Wage2 & Wage1 & Wage2 \\
\hline Const & 6,01 & 6,07 & 10,34 & 10,51 & 6.14 & 6.19 & 10.49 & 10.54 & 5.73 & 5.85 & 10.03 & 10.33 \\
\hline Cand. Or Dr. of sciences & 0,65 & 0,85 & 0,97 & 0,87 & 0.60 & 0.95 & 0.86 & 0.90 & 0.70 & 0.69 & 1.26 & 0.95 \\
\hline Unversity degree & 0,71 & 0,72 & 0,75 & 0,70 & 0.58 & 0.74 & 0.65 & 0.74 & 0.85 & 0.71 & 0.85 & 0.67 \\
\hline Technical school & 0,46 & 0,43 & 0,47 & 0,41 & 0.42 & 0.52 & 0.48 & 0.58 & 0.54 & 0.39 & 0.48 & 0.30 \\
\hline Vocational school & 0,18 & 0,24 & 0,33 & 0,31 & 0.18 & 0.34 & 0.36 & 0.48 & 0.22 & 0.17 & 0.33 & 0.16 \\
\hline Gen. And special sec. sch. & 0,21 & 0,23 & 0,23 & 0,17 & 0.19 & 0.34 & 0.24 & 0.30 & 0.27 & 0.15 & 0.25 & $0.08 * *$ \\
\hline PWE & 0,055 & 0,031 & 0,061 & 0,030 & 0.05 & 0.02 & 0.06 & 0.024 & 0.052 & 0.04 & 0.063 & 0.03 \\
\hline $\mathrm{PWE}^{\wedge} 2$ & $-0,001$ & 0,000 & $-0,001$ & 0,000 & -0.001 & -0.0002 & -0.0012 & -0.002 & -0.001 & -0.0004 & -0.001 & -0.0004 \\
\hline Women & $-0,20$ & $-0,18$ & $-0,19$ & $-0,20$ & - & - & - & - & - & - & - & - \\
\hline Self-employed & 0,51 & 0,80 & 0,10 & 0,45 & 0.59 & 0.65 & $-0.03 \dagger$ & 0.36 & $0.18 \dagger$ & 0.18 & 0.40 & 0.60 \\
\hline Serving in the army & 0,62 & 0,71 & 0,30 & 0,39 & 0.62 & 0.66 & $0.16^{*}$ & $0.34 * *$ & 0.66 & 1.11 & 0.51 & 0.63 \\
\hline Disabled & $-0,99$ & $-0,41$ & $-0,88$ & $-0,50$ & -1.18 & -0.45 & $-0.40 * *$ & -0.47 & -0.6 & -0.35 & -1.73 & -0.50 \\
\hline Chernobyl & $-0,01$ & $-0,01$ & $-0,20$ & $-0,11$ & -0.04 & $-0.03 \dagger$ & -0.20 & -0.08 & -0.006 & 0.008 & -0.19 & -0.12 \\
\hline$\overline{\mathrm{N} \text { obs }}$ & 6454 & 9546 & 6349 & 9312 & 3237 & 4292 & 3061 & 4136 & 3217 & 5254 & 3288 & 5176 \\
\hline $\mathrm{R}^{2}$ & 0.25 & 0.24 & 0.21 & 0.18 & 0.26 & 0.23 & 0.19 & 0.17 & 0.26 & 0.24 & 0.23 & 0.18 \\
\hline Adj.- $R^{2}$ & 0.24 & 0.24 & 0.20 & 0.18 & 0.25 & 0.22 & 0.18 & 0.16 & 0.25 & 0.23 & 0.22 & 0.17 \\
\hline
\end{tabular}

Note:

${ }^{a}+$ not significant; * significant at 10\%,**-significant at 5\%, if no mark-significant at $1 \%$.

${ }^{b}$ PWE means potential work experience.

${ }^{c}$ The baselines are compulsory education and Minsk city. Eighteen regional dummies were also included, but not reported. The dummies are obtained dividing each of the six oblasts in which the country is divided in three subregions, relative to areas with large cities, small cities and rural areas.

${ }^{d}$ A dummy for individuals not providing information on the type of education attainment is also added.

e The Huber/White/sandwich estimator of variance is used in place of the traditional calculation to correct for heteroskedasticity.

Source: elaboration on the BHSIE. 
Table 5. Results of Oaxaca and Ransom decomposition based on monthly wages from the main job.

\begin{tabular}{|c|c|c|c|c|c|c|c|c|c|c|}
\hline \multirow[b]{2}{*}{ Variables } & \multicolumn{5}{|c|}{1996} & \multicolumn{5}{|c|}{2001} \\
\hline & $\begin{array}{l}\text { Coefficient } \\
\text { estimate } \\
\text { (1) }\end{array}$ & $\begin{array}{l}\text { Coefficient } \\
\text { estimate } \\
\text { (2) }\end{array}$ & $\begin{array}{l}\text { Mean } \\
\text { difference: } \\
\text { M-F } \\
\text { (3) }\end{array}$ & $\begin{array}{c}\text { Absolute } \\
\text { contribution } \\
\text { to the wage } \\
\text { gap } \\
(2)^{*}(3)\end{array}$ & $\begin{array}{l}\text { Relative } \\
\text { contribution } \\
\text { to the wage gap } \\
(2)^{*}(3) /(1)\end{array}$ & $\begin{array}{l}\text { Coefficient } \\
\text { estimate } \\
\text { (4) }\end{array}$ & $\begin{array}{c}\text { Coefficient } \\
\text { estimate } \\
\text { (5) }\end{array}$ & $\begin{array}{c}\text { Mean } \\
\text { difference: M- } \\
\text { F } \\
(6)\end{array}$ & $\begin{array}{c}\text { Absolute } \\
\text { contribution } \\
\text { to wage gap } \\
(5)^{*}(6)\end{array}$ & $\begin{array}{c}\text { Relative } \\
\text { contribution } \\
\text { to wage gap } \\
(4)^{*}(5) /(4)\end{array}$ \\
\hline Wage & $\ldots$ & & 0,126 & & & $\ldots$ & & 0,120 & & \\
\hline Cand. Or & $\ldots$ & & & & & $\ldots$ & & & & \\
\hline $\begin{array}{l}\text { Dr. of } \\
\text { sciences }\end{array}$ & & 0,651 & 0,003 & 0,002 & 0,016 & & 0,969 & 0,003 & 0,003 & 0,031 \\
\hline $\begin{array}{l}\text { Unversity } \\
\text { degree }\end{array}$ & $\cdots$ & 0,705 & $-0,030$ & $-0,021$ & $-0,186$ & $\cdots$ & 0,746 & $-0,034$ & $-0,025$ & $-0,242$ \\
\hline $\begin{array}{l}\text { Technical } \\
\text { school }\end{array}$ & $\cdots$ & 0,462 & $-0,123$ & $-0,057$ & $-0,497$ & $\cdots$ & 0,469 & $-0,114$ & $-0,054$ & $-0,509$ \\
\hline $\begin{array}{l}\text { Vocational } \\
\text { school }\end{array}$ & $\cdots$ & 0,184 & 0,079 & 0,014 & 0,127 & $\cdots$ & 0,332 & 0,064 & 0,021 & 0,201 \\
\hline $\begin{array}{l}\text { Gen. And } \\
\text { special sec. }\end{array}$ & $\cdots$ & & & & & $\cdots$ & & & & \\
\hline sch. & & 0,210 & 0,030 & 0,006 & 0,055 & & 0,226 & 0,062 & 0,014 & 0,133 \\
\hline PWE & $\ldots$ & 0,055 & 0,664 & 0,037 & 0,320 & $\ldots$ & 0,061 & 0,345 & 0,021 & 0,199 \\
\hline $\mathrm{PWE}^{\wedge} 2$ & $\ldots$ & $-0,001$ & 38,525 & $-0,042$ & $-0,370$ & $\ldots$ & $-0,001$ & 32,838 & $-0,039$ & $-0,371$ \\
\hline Women & -0.114 & $-0,196$ & 0,000 & 0,196 & 1.714 & -0.105 & $-0,189$ & $-1,000$ & 0,189 & 1,793 \\
\hline $\begin{array}{l}\text { Self- } \\
\text { employed }\end{array}$ & $\ldots$ & 0,511 & $-1,000$ & 0,002 & 0,017 & $\ldots$ & 0,104 & 0,009 & 0,001 & 0,008 \\
\hline $\begin{array}{l}\text { Serving in } \\
\text { the army }\end{array}$ & $\ldots$ & 0,616 & 0,004 & 0,014 & 0,125 & $\ldots$ & 0,302 & 0,018 & 0,006 & 0,053 \\
\hline Disabled & $\ldots$ & $-0,990$ & 0,023 & $-0,002$ & $-0,013$ & $\ldots$ & $-0,880$ & 0,001 & $-0,001$ & $-0,012$ \\
\hline Chernobyl & $\ldots$ & $-0,012$ & 0,002 & 0,000 & 0,001 & $\ldots$ & $-0,203$ & $-0,022$ & 0,005 & 0,043 \\
\hline Brestru & $\ldots$ & $-0,791$ & $-0,006$ & $-0,006$ & $-0,055$ & $\ldots$ & $-0,471$ & 0,009 & $-0,004$ & $-0,040$ \\
\hline Brestsm & $\ldots$ & $-0,361$ & 0,008 & 0,002 & 0,015 & $\ldots$ & $-0,155$ & $-0,003$ & 0,000 & 0,004 \\
\hline Brestlar & $\ldots$ & $-0,157$ & $-0,005$ & 0,001 & 0,008 & $\ldots$ & $-0,124$ & $-0,009$ & 0,001 & 0,011 \\
\hline Gomelru & $\ldots$ & $-0,455$ & $-0,006$ & $-0,004$ & $-0,033$ & $\ldots$ & $-0,589$ & 0,006 & $-0,004$ & $-0,035$ \\
\hline Gomelsm & $\ldots$ & $-0,166$ & 0,008 & 0,001 & 0,005 & $\ldots$ & $-0,054$ & $-0,002$ & 0,000 & 0,001 \\
\hline Gomellar & $\ldots$ & $-0,222$ & $-0,004$ & 0,000 & $-0,002$ & $\ldots$ & $-0,153$ & 0,000 & 0,000 & 0,000 \\
\hline Grodnlar & $\ldots$ & 0,002 & 0,001 & 0,000 & 0,000 & $\ldots$ & $-0,052$ & $-0,001$ & 0,000 & 0,000 \\
\hline Grodnru & $\ldots$ & $-0,424$ & $-0,003$ & $-0,003$ & $-0,028$ & $\ldots$ & $-0,492$ & 0,015 & $-0,007$ & $-0,070$ \\
\hline Grodnsm & $\ldots$ & $-0,216$ & 0,008 & 0,000 & 0,001 & $\ldots$ & $-0,166$ & $-0,005$ & 0,001 & 0,008 \\
\hline Minskru & $\ldots$ & $-0,627$ & $-0,001$ & $-0,008$ & $-0,071$ & $\ldots$ & $-0,308$ & 0,004 & $-0,001$ & $-0,011$ \\
\hline Minsksm & $\ldots$ & $-0,330$ & 0,013 & 0,002 & 0,019 & $\ldots$ & $-0,148$ & 0,001 & 0,000 & $-0,001$ \\
\hline Minsklar & $\ldots$ & $-0,049$ & $-0,007$ & 0,000 & 0,000 & $\ldots$ & $-0,032$ & 0,003 & 0,000 & $-0,001$ \\
\hline Viteblar & $\ldots$ & $-0,207$ & 0,001 & 0,001 & 0,009 & $\ldots$ & $-0,098$ & $-0,010$ & 0,001 & 0,010 \\
\hline Vitebru & $\ldots$ & $-0,629$ & $-0,005$ & $-0,006$ & $-0,055$ & $\ldots$ & $-0,486$ & 0,008 & $-0,004$ & $-0,037$ \\
\hline Vitebsm & $\ldots$ & $-0,258$ & 0,010 & 0,000 & 0,000 & $\ldots$ & $-0,232$ & 0,000 & 0,000 & 0,000 \\
\hline Mogillar & $\ldots$ & $-0,135$ & 0,000 & 0,001 & 0,009 & $\ldots$ & $-0,081$ & $-0,003$ & 0,000 & 0,002 \\
\hline Mogilru & $\ldots$ & $-0,300$ & $-0,007$ & $-0,002$ & $-0,016$ & $\ldots$ & $-0,532$ & 0,004 & $-0,002$ & $-0,020$ \\
\hline Mogilsm & $\ldots$ & $-0,328$ & 0,006 & $-0,001$ & $-0,006$ & $\ldots$ & $-0,334$ & 0,002 & $-0,001$ & $-0,005$ \\
\hline cons & $\ldots$ & 6,013 & & & & $\ldots$ & 10,342 & & & \\
\hline
\end{tabular}

Notes: Column (1) and (4), the female dummy estimate is based on a regression in which no other explanatory variables are used; column (2 and (5)), covariates in pooled-data regression. For each of the regions (See Table AI), there are three dummies representing rural areas, small and large towns.

Source: elaboration on the BHSIE 
Table 6. Results of Oaxaca and Ransom decomposition based on total monthly income.

\begin{tabular}{|c|c|c|c|c|c|c|c|c|c|c|}
\hline \multirow[b]{2}{*}{ Variables } & \multicolumn{5}{|c|}{1996} & \multicolumn{5}{|c|}{2001} \\
\hline & $\begin{array}{l}\text { Coefficient } \\
\text { estimate } \\
\text { (1) }\end{array}$ & $\begin{array}{l}\text { Coefficient } \\
\text { estimate } \\
\text { (2) }\end{array}$ & $\begin{array}{c}\text { Mean } \\
\text { difference : } \\
\text { M-F (3) }\end{array}$ & $\begin{array}{c}\text { Absolute } \\
\text { contribution } \\
\text { to wage gap } \\
(2)^{*}(3)\end{array}$ & $\begin{array}{c}\text { Relative } \\
\text { contribution } \\
\text { to wage gap } \\
(2)^{*}(3) /(1)\end{array}$ & $\begin{array}{c}\text { Coefficient } \\
\text { estimate } \\
\text { (4) }\end{array}$ & $\begin{array}{l}\text { Coefficient } \\
\text { estimate } \\
\text { (5) }\end{array}$ & $\begin{array}{c}\text { Mean } \\
\text { difference : } \\
\text { M-F (6) }\end{array}$ & $\begin{array}{c}\text { Absolute } \\
\text { contribution } \\
\text { to wage gap } \\
(5)^{*}(6)\end{array}$ & $\begin{array}{c}\text { Relative } \\
\text { contribution } \\
\text { to wage gap } \\
(4)^{*}(5) /(4)\end{array}$ \\
\hline Wage & $\ldots$ & & 0,187 & & & $\cdots$ & & 0,185 & & \\
\hline Phd & $\ldots$ & 0,846 & 0,003 & 0,002 & 0,013 & $\ldots$ & 0,871 & 0,003 & 0,003 & 0,018 \\
\hline laurea1 & $\ldots$ & 0,720 & 0,007 & 0,005 & 0,029 & $\ldots$ & 0,699 & 0,001 & 0,001 & 0,006 \\
\hline Techsec1 & $\ldots$ & 0,434 & $-0,079$ & $-0,034$ & $-0,200$ & $\ldots$ & 0,408 & $-0,075$ & $-0,031$ & $-0,179$ \\
\hline vocsec2 & $\ldots$ & 0,242 & 0,096 & 0,023 & 0,136 & $\ldots$ & 0,306 & 0,067 & 0,021 & 0,121 \\
\hline gensec 1 & $\ldots$ & 0,229 & 0,043 & 0,010 & 0,057 & $\ldots$ & 0,167 & 0,065 & 0,011 & 0,064 \\
\hline PWE & $\ldots$ & 0,031 & $-4,772$ & $-0,150$ & $-0,879$ & $\ldots$ & 0,030 & $-4,304$ & $-0,129$ & $-0,754$ \\
\hline $\mathrm{PWE}^{\wedge} 2$ & $\ldots$ & 0,000 & $-385,304$ & 0,136 & 0,798 & $\ldots$ & 0,000 & $-330,214$ & 0,110 & 0,643 \\
\hline Women & -0.171 & $-0,184$ & $-1,000$ & 0,184 & 1,075 & -0.170 & $-0,195$ & $-1,000$ & 0,195 & 1,140 \\
\hline $\begin{array}{l}\text { Selfempl } \\
\text { oyed }\end{array}$ & $\ldots$ & 0,800 & 0,004 & 0,003 & 0,019 & $\ldots$ & 0,447 & 0,014 & 0,006 & 0,036 \\
\hline $\begin{array}{l}\text { Serving } \\
\text { in the }\end{array}$ & $\cdots$ & & & & & $\cdots$ & & & & \\
\hline army & & 0,708 & 0,018 & 0,013 & 0,073 & & 0,390 & 0,014 & 0,005 & 0,032 \\
\hline Disabled & $\ldots$ & $-0,412$ & 0,006 & $-0,003$ & $-0,015$ & $\ldots$ & $-0,495$ & 0,006 & $-0,003$ & $-0,018$ \\
\hline Chernoby & $\ldots$ & & & & & $\ldots$ & & & & \\
\hline 1 & & $-0,005$ & $-0,006$ & 0,000 & 0,000 & & $-0,108$ & $-0,020$ & 0,002 & 0,013 \\
\hline Brestru & $\ldots$ & $-0,544$ & 0,002 & $-0,001$ & $-0,006$ & $\ldots$ & $-0,394$ & 0,011 & $-0,004$ & $-0,026$ \\
\hline Brestsm & $\ldots$ & $-0,334$ & 0,000 & 0,000 & 0,000 & $\ldots$ & $-0,133$ & 0,000 & 0,000 & 0,000 \\
\hline Brestlar & $\ldots$ & $-0,161$ & $-0,004$ & 0,001 & 0,004 & $\ldots$ & $-0,146$ & $-0,009$ & 0,001 & 0,008 \\
\hline Gomelru & $\ldots$ & $-0,345$ & 0,000 & 0,000 & 0,000 & $\ldots$ & $-0,338$ & 0,002 & $-0,001$ & $-0,005$ \\
\hline Gomelsm & $\ldots$ & $-0,155$ & $-0,002$ & 0,000 & 0,002 & $\ldots$ & $-0,073$ & 0,001 & 0,000 & 0,000 \\
\hline Gomellar & $\ldots$ & $-0,211$ & 0,001 & 0,000 & $-0,001$ & $\ldots$ & $-0,125$ & 0,004 & $-0,001$ & $-0,003$ \\
\hline Grodnlar & $\ldots$ & 0,015 & 0,003 & 0,000 & 0,000 & $\ldots$ & $-0,069$ & $-0,003$ & 0,000 & 0,001 \\
\hline Grodnru & $\ldots$ & $-0,390$ & 0,005 & $-0,002$ & $-0,010$ & $\ldots$ & $-0,332$ & 0,007 & $-0,002$ & $-0,013$ \\
\hline Grodnsm & $\ldots$ & $-0,241$ & 0,004 & $-0,001$ & $-0,005$ & $\ldots$ & $-0,171$ & $-0,001$ & 0,000 & 0,001 \\
\hline Minskru & $\ldots$ & $-0,422$ & 0,000 & 0,000 & 0,001 & $\ldots$ & $-0,189$ & $-0,002$ & 0,000 & 0,003 \\
\hline Minsksm & $\ldots$ & $-0,269$ & 0,000 & 0,000 & 0,000 & $\ldots$ & $-0,101$ & 0,001 & 0,000 & $-0,001$ \\
\hline Minsklar & $\ldots$ & $-0,068$ & $-0,002$ & 0,000 & 0,001 & $\ldots$ & $-0,036$ & 0,002 & 0,000 & 0,000 \\
\hline Viteblar & $\ldots$ & $-0,177$ & $-0,005$ & 0,001 & 0,005 & $\ldots$ & $-0,109$ & $-0,011$ & 0,001 & 0,007 \\
\hline Vitebru & $\ldots$ & $-0,469$ & $-0,002$ & 0,001 & 0,005 & $\ldots$ & $-0,327$ & 0,004 & $-0,001$ & $-0,009$ \\
\hline Vitebsm & $\ldots$ & $-0,231$ & 0,002 & $-0,001$ & $-0,003$ & $\ldots$ & $-0,126$ & $-0,002$ & 0,000 & 0,001 \\
\hline Mogillar & $\ldots$ & $-0,139$ & $-0,001$ & 0,000 & 0,001 & $\ldots$ & $-0,038$ & $-0,002$ & 0,000 & 0,001 \\
\hline Mogilru & $\ldots$ & $-0,315$ & 0,002 & $-0,001$ & $-0,004$ & $\ldots$ & $-0,311$ & 0,001 & 0,000 & $-0,002$ \\
\hline Mogilsm & $\ldots$ & $-0,298$ & 0,001 & 0,000 & $-0,003$ & $\ldots$ & $-0,220$ & 0,002 & 0,000 & $-0,003$ \\
\hline cons & $\ldots$ & 6,070 & & & & $\ldots$ & 10,513 & & & \\
\hline
\end{tabular}

Notes: See the Notes to Table 5.

Source: elaboration on the BHSIE 
Table 7. Regional distribution of wages

\begin{tabular}{lllll}
\hline Regions & $\ln ($ wage1 $)$ & $\ln ($ wage3) & wage1 & wage3 \\
\hline Brest oblast & 6.270301 & 6.320193 & 304.7625 & 718.3346 \\
Vitebsk oblast & 6.356405 & 6.395623 & 320.5343 & 765.5943 \\
Gomel oblast & 6.448558 & 6.466743 & 387.507 & 806.6024 \\
Grodno oblast & 6.543616 & 6.514643 & 405.939 & 864.7016 \\
Minsk & 6.820832 & 6.822797 & 612.5017 & 1213.406 \\
Minsk oblast & 6.3161 & 6.390187 & 341.2275 & 743.8739 \\
Mogilev oblast & 6.522949 & 6.490924 & 375.7838 & 833.1553
\end{tabular}

Source: elaboration on the BHSIE. 


\section{Appendix}

Table A1. Variables definition

\begin{tabular}{ll}
\hline Variable name & Definition \\
\hline Ln $($ Wage $n), n=1,2$ & The dependent variable is represented by the natural logarithm of \\
& different types of incomes. The figures are computed by the \\
& Ministry of Statistics as an average of the wage declared by the \\
& worker, taking into account the number of months for which he \\
& received a wage.
\end{tabular}

Wage1 Net monthly wages, measured as an average value during the year. According to the questionnaire, monthly wages incorporates "Payment for work in cash from the main job including subsidies, benefits and dividends after deducting payroll, other taxes and alimonies".

Wage2

Years of potential work experience $=$ total monthly labour income. In other words, wage $1+$ plus subsidies, earnings from secondary job holding, pensions and other types of incomes.

$=$ age - education -6 .

Postgraduate degree (candidate or doctor of $=1$, if candidate or doctor of science; $=0$, otherwise (equivalent on science; aspirantura and doctorantura); University degree average to 20 years of schooling)

$=1$, if University degree; $=0$, otherwise (equivalent on average to 16 years of schooling)

Technical school

(Technical or specialised high secondary school; technikum);

Vocational education

(Vocational Secondary Education; PTU, proftechuchilishche);

General secondary education

(General Secondary Education; obshcheobrazovatelanaya shkola) ${ }^{1}$

Compulsory education

(Low secondary school)

Primary education (nachalnaya shkola)

Regional unemployment

$=1$, if diploma of technical secondary school; $=0$, otherwise (equivalent on average to 13 years of schooling)

$=1$, if diploma of vocational secondary school; $=0$, otherwise (equivalent on average to 12 years of schooling)

$=1$, if diploma of general secondary school; $=0$, otherwise (equivalent on average to 11 years of schooling).

$=1$, if diploma of basic school; $=0$, otherwise (equivalent on average to 9 years of schooling)

$=1$ if primary education; $=0$ otherwise (equivalent on average to 4 years of schooling)

Seven regions are considered: Brest oblast, Vitebsk oblast, Gomel oblast, Grodno oblast, Minsk city, Minsk oblast, Mogilev oblast.

Chernobyl

$=1$, if a person was seriously affected by the Chernobyl disaster; = 0 , otherwise

Note: General secondary education includes also special types of secondary school: Gymnasium; Lyceum;

Specialized schools. 